\title{
Generalized Transduction in Rhizobium leguminosarum
}

\author{
By VICKY BUCHANAN-WOLLASTON \\ John Innes Institute, Colney Lane, Norwich NR4 $7 U H$
}

(Received 16 October 1978)

\begin{abstract}
Generalized transduction in Rhizobium leguminosarum by two virulent bacteriophages, RL38 and RL39, is described. The transduction frequency was increased by ultraviolet irradiation of phage lysates. Cotransduction of auxotrophic and antibiotic resistance markers was shown, as was transduction of two P1 group R plasmids. Transduction between strains of Rhizobium trifolii and interspecific transduction from $R$. leguminosarum to $R$. trifolii occurred but no transduction from $R$. trifolii to $R$. leguminosarum was detected.
\end{abstract}

\section{INTRODUCTION}

Transduction of Rhizobium species has previously been reported only in Rhizobium meliloti. Kowalski $(1967,1970)$ showed that a number of $R$. meliloti phages were capable of generalized transduction; one (L5) transduced several auxotrophic markers and cotransduced a leu marker with symbiotic ineffectiveness (Kowalski, 1974). Sváb et al. (1978) showed that the phage 16.3 of $R$. meliloti is a specialized transducing phage for a cysteine marker.

Linkage maps, constructed by $\mathrm{R}$ plasmid-mediated recombination, are available for $R$. meliloti (Meade \& Signer, 1977; Kondorosi et al., 1977) and R. leguminosarum (Beringer et al., 1978a). Interspecific recombination between $R$. leguminosarum, $R$. trifolii and $R$. phaseoli has also been shown (Johnston \& Beringer, 1977). No transduction system for fine structure mapping has previously been reported for these other species. This paper describes generalized transducing phages, RL38 and RL39, which have been used for transduction in $R$. leguminosarum and $R$. trifolii and for transduction between these two species.

\section{METHODS}

Bacterial strains. These are shown in Table 1.

Media. Minimal medium (SY) was as described by Beringer (1974). Phages were propagated on modified SY medium containing $0.05 \%(\mathrm{w} / \mathrm{v})$ glucose instead of sodium succinate. Soft $\mathrm{Y}$, used for top layers, was SY medium containing $0.6 \%(\mathrm{w} / \mathrm{v})$ Difco agar and was supplemented with sodium succinate, sodium glutamate and vitamin solution (as SY) before autoclaving. VS was Vincent's (1970) phage broth. Escherichia coli strains were grown on Oxoid nutrient agar (NA).

Antibiotics. These were used at the following final concentrations $\left(\mathrm{mg}^{-1}\right)$ : kanamycin sulphate, 20; streptomycin sulphate, 200; rifampicin, 20; tetracycline hydrochloride, 10; spectinomycin sulphate, 200; gentamicin sulphate, 10. For E. coli, gentamicin sulphate was used at $5 \mathrm{mg} \mathrm{l}^{-1}$.

Phage isolation. Soil samples were collected locally and shaken overnight in an exponential phase culture (approx. $50 \mathrm{ml}$ ) of $R$. leguminosarum strain 1682. The culture was then centrifuged and the supernatant was filtered through a $0.45 \mu \mathrm{m}$ pore size Millipore membrane. The filtrate was plated in soft agar top layers seeded with bacteria to detect phages. Plaques were picked and purified by two single-plaque isolations. Phages were stored in VS over chloroform.

Preparation of phage lysates and bacterial cultures. Phage lysates were prepared by the method described by Adams (1959). Bacteria and phages were mixed in a top layer to give confluent lysis after $2 \mathrm{~d}$ growth at $28^{\circ} \mathrm{C}$. VS $(3 \mathrm{ml})$ was then added to the plates, left for $2 \mathrm{~h}$ to elute the phages and collected. Lysates were sterilized with chloroform. Titres of up to $10^{9}$ plaque-forming units (p.f.u.) $\mathrm{ml}^{-1}$ were obtained by this method. 
Table 1. Bacterial strains and plasmids

\begin{tabular}{|c|c|c|c|}
\hline Strain & Species & Genotype & Reference or source \\
\hline 1055 & Rhizobium leguminosarum & ura-14 met-14 & This laboratory \\
\hline 1682 & R. leguminosarum & phe-1 trp-14 rif-66 str-273 spc-15 & This laboratory \\
\hline 1497 & R. leguminosarum & phe-1 trp-14 rif-66 spc-15 & This laboratory \\
\hline 1086 & R. leguminosarum & liv-1 cys-9 str-91 & This laboratory \\
\hline 1683 & R. leguminosarum & phe-1 trp-14 str-36 spc-15 (R68.45) & This laboratory \\
\hline 1057 & R. leguminosarum & ura-14 met-14 rif-74 & This laboratory \\
\hline 1245 & R. leguminosarum & ser-1 (R68.45) & This laboratory \\
\hline 1380 & R. leguminosarum & phe-1 met -12 rib-2 str- 69 & This laboratory \\
\hline 1446 & R. leguminosarum & trp-14 ura-14 str-69 & This laboratory \\
\hline 1504 & R. leguminosarum & phe-1 ade-71 str-112 & This laboratory \\
\hline 1569 & R. leguminosarum & phe-1 ade-72 rif-304 & This laboratory \\
\hline 1703 & R. leguminosarum & trp-49 his-16 rif-19 spc-52 & This laboratory \\
\hline 6710 & R. trifolii & rif -258 & Johnston et al. $(1978 b)$ \\
\hline T72 & R. trifolii & str-144liv $v_{-}^{*} 9$ & This laboratory \\
\hline $\mathrm{T} 153$ & R. trifolii & str-144 spc-26 trp ${ }^{*}-59$ & This laboratory \\
\hline T94 & R. leguminosarum & ura-14 trp-16 str-69 ade ${ }^{*}-91$ & Beringer et al. $(1978 b)$ \\
\hline 2202 & R. leguminosarum & phe-1 trp-12 str-37 (pPH1JI) & Hirsch (1978) \\
\hline 402 & Escherichia coli & pro met nal & E. Meynell \\
\hline
\end{tabular}

\begin{tabular}{lcl} 
Plasmid & Antibiotic resistances $\dagger$ & \multicolumn{1}{c}{ Reference } \\
R68.45 & Ap Km Tc & Haas \& Holloway (1976) \\
pPH1JI & Ge Sp & Hirsch (1978)
\end{tabular}

All $R$. leguminosarum strains are derivatives of wild-type strain 300 (Johnston \& Beringer, 1975). All $R$. trifolii strains are derivatives of wild-type strain 6621 (strain 204 in the Rothamsted Culture Collection). Auxotrophic markers were introduced by $N$-methyl- $N^{\prime}$-nitro- $N$-nitrosoguanidine mutagenesis or transposon $\left.{ }^{*}\right)$ mutagenesis; antibiotic resistances were spontaneous.

* T strains carry the transposon Tn5 and insertion has induced the auxotrophy indicated by the asterisk.

$\dagger$ Abbreviations for plasmid-mediated antibiotic resistances: Ap, ampicillin; Km, Kanamycin; Tc, tetracycline; Ge, gentamicin; $\mathrm{Sp}$, spectinomycin.

Recipient bacteria for transduction experiments were prepared by growing shaken cultures at $28{ }^{\circ} \mathrm{C}$ in VS to late-exponential phase. Bacteria were centrifuged, washed twice in $0.9 \%(\mathrm{w} / \mathrm{v})$ saline and resuspended in VS.

Transduction. Equal volumes of recipient bacteria and phage lysate were mixed to give a multiplicity of infection of about one. The transduction mixture was incubated at $28^{\circ} \mathrm{C}$ for $3 \mathrm{~h}$. To select for transduction of prototrophic alleles or $\mathbf{R}$ plasmids, the mixture was then plated directly on selective media. To select for transduction of rifampicin and/or streptomycin resistances, the mixture was plated on minimal medium without antibiotic, left for $18 \mathrm{~h}$ at room temperature to allow for phenotypic expression, and then overlaid with soft $\dot{Y}(3 \mathrm{ml}$ per plate) containing rifampicin and/or streptomycin. Plates were incubated for $6 \mathrm{~d}$ at $28{ }^{\circ} \mathrm{C}$ before scoring.

Ultraviolet light (u.v.) treatment of phages. Phage lysate $(3 \mathrm{ml})$ was placed in a plastic Petri dish $(50 \mathrm{~mm}$ diam.) and irradiated with ultraviolet light at a dose rate of approximately $2 \mathrm{~J} \mathrm{~m}^{-2} \mathrm{~s}^{-1}$.

\section{RESULTS}

\section{Isolation of transducing phages}

Rifampicin and streptomycin resistance markers have been shown by conjugation to be closely linked on the R. leguminosarum chromosome (Beringer \& Hopwood, 1976). Therefore cotransduction of these two markers should be possible and selection for coinheritance of both allows rapid screening for transducing phages since the possibility of selecting spontaneous mutants is negligible. Twenty-six different phage isolates were tested for their ability to transduce these markers from $R$. leguminosarum strain 1682 to strain 1055 . Two of these, RL38 and RL39, transduced at frequencies greater than $10^{-8}$. Phage RL38 transduced at a frequency tenfold higher than RL39 and was used in the majority of experiments. 


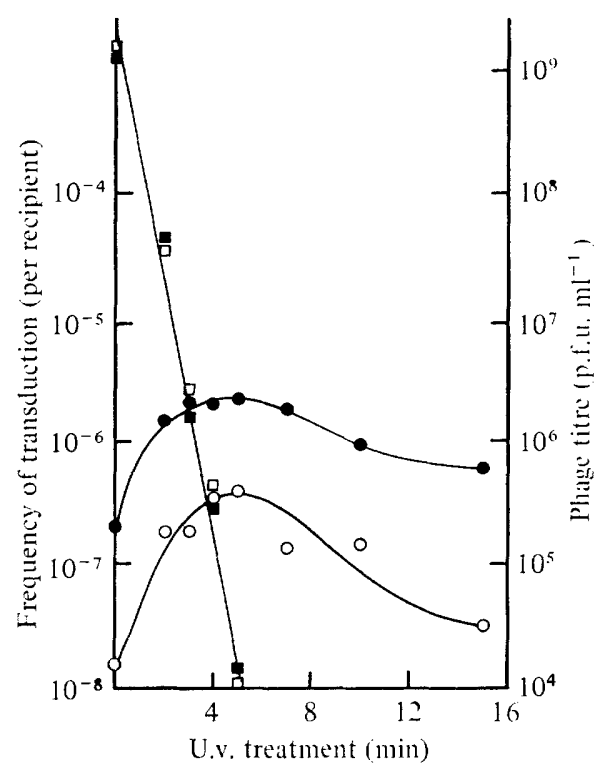

Fig. 1. Effect of u.v. irradiation on the viability of RL38 ( $\square$ ) and RL39 ( $\square$ ) and on the frequency of cotransduction of rifampicin and streptomycin resistance by RL38 (O) and RL39 (O) from R. leguminosarum strain 1682 to 1055 .

\section{Effect of u.v. irradiation}

Ely \& Johnson (1977) showed that transduction in Caulobacter crescentus by phage $\phi \mathrm{Cr} 30$ was improved when phage lysates were exposed to u.v. irradiation to $0 \cdot 1 \%$ survival. A similar effect was found for RL38 and RL39 (Fig. 1). The optimum time of u.v. irradiation was $5 \mathrm{~min}$ and this treatment was used routinely in all subsequent experiments. During this period of irradiation the plaque-forming titre of the lysate fell from approximately $10^{9}$ to approximately $10^{5}$ p.f.u. $\mathrm{ml}^{-1}$ (Fig. 1).

\section{Phage properties}

RL38 and RL39 are probably virulent phages. All the phages isolated to date produced turbid plaques on the medium used for propagation of $R$. leguminosarum phages. However, the plaques of RL38 and RL39 were clearer than those of known lysogenic $R$. leguminosarum phages RL27 and RL30 (Buchanan-Wollaston, 1977). Bacteria from the centres of several turbid plaques were streaked to give single colonies and tested for sensitivity to the relevant phage by spot tests. All of 128 single colonies tested were sensitive, indicating that the turbidity of the plaques was not due to the formation of lysogenic bacteria.

Phages RL38 and RL39 adsorb very slowly to the bacteria; approximately $90 \%$ adsorption occurred in $3 \mathrm{~h}$ (unpublished results). Washing the bacteria with $0.9 \%$ (w/v) saline improved adsorption, presumably by removing some of the surface polysaccharide.

\section{Linkage of rif, str and spc alleles}

In $R$. leguminosarum, rif, str and some $s p c$ alleles map very closely by R68.45-mediated recombination (unpublished results). Cotransduction of the three markers by RL38 was shown (Table 2), indicating that they are closely linked. Transductants carrying the donor genotype always formed the largest class, and therefore the distances between the three markers must be small compared with the length of the transduced fragments.

The sequence rif-str-spc is consistent with the data in Table 2. In the three crosses the smallest transductant class was produced either by a quadruple crossover event (first and 
Table 2. Three-factor transduction crosses to determine the order of rif, str and spc markers in R. leguminosarum



third crosses), or by a double crossover occurring in the intervals between the three markers (second cross).

\section{Transduction of auxotrophic markers}

Table 3 shows the auxotrophic markers that were transduced to prototrophy in derivatives of $R$. leguminosarum strain 300 . The frequencies shown are for RL38 and they varied only by a factor of 10 for different markers. Table 4 shows the cotransduction of auxotrophic markers by RL38. There is a correlation between the coinheritance frequencies obtained by transduction and those obtained by conjugation.

\section{Transduction of plasmids}

Two P1 group R plasmids, R68.45 and pPH1JI, were transduced by RL38 and RL39 (Table 5). These plasmids have molecular weights of $37 \cdot 4 \times 10^{6}$ and $32 \times 10^{6}$, respectively (Jacob et al., 1977; Hirsch, 1978). Transductants were tested for the unselected drug resistance carried on the $\mathrm{R}$ plasmid and their ability to conjugate was tested in patch crosses (Johnston et al., 1978a). Transductants were mixed with another $R$. leguminosarum strain, or with $E$. coli strain 402 , left overnight and then replicated to selective media to check for R plasmid transfer. Escherichia coli crosses were replicated to NA supplemented with the relevant antibiotic. The ampicillin resistance carried on R68.45 is expressed in $E$. coli though not in $R$. leguminosarum (Beringer, 1974). In all cases, transduced plasmids carried the same drug resistances as the parent and remained conjugative. 
Table 3. Transduction of auxotrophic markers in R. leguminosarum

\begin{tabular}{|c|c|c|c|c|c|}
\hline $\begin{array}{l}\text { Donor } \\
\text { strain }\end{array}$ & $\begin{array}{l}\text { Recipient } \\
\text { strain }\end{array}$ & $\begin{array}{l}\text { Selected } \\
\text { allele }\end{array}$ & $\begin{array}{c}\text { No. of colonies } \\
\text { with selected } \\
\text { phenotype }\end{array}$ & $\begin{array}{c}\text { Transduction } \\
\text { frequency } \\
\text { (per recipient) }\end{array}$ & $\begin{array}{l}\text { Spontaneous } \\
\text { reversion } \\
\text { frequency (per } \\
\text { recipient) }\end{array}$ \\
\hline 1086 & 1497 & $\operatorname{trp}-14^{+}$ & 1734 & $3 \times 10^{-6}$ & $<10^{-8}$ \\
\hline 1086 & 1497 & phe-1+ & 600 & $8 \times 10^{-7}$ & $1 \times 10^{-8}$ \\
\hline 1497 & 1086 & cys $-9^{+}$ & 2560 & $5 \times 10^{-6}$ & $4 \times 10^{-8}$ \\
\hline 1683 & 1245 & ser- $1^{+}$ & 328 & $3 \times 10^{-6}$ & $<10^{-8}$ \\
\hline 1380 & 1446 & ura- $14^{+}$ & 200 & $2 \times 10^{-6}$ & $<10^{-8}$ \\
\hline 1446 & 1380 & met $-12^{+}$ & 1120 & $6 \times 10^{-6}$ & $<10^{-8}$ \\
\hline 1380 & 1504 & ade- $71^{+}$ & 212 & $8 \times 10^{-7}$ & $<10^{-8}$ \\
\hline 1446 & 1569 & ade $-72^{+}$ & 436 & $2 \times 10^{-6}$ & $<10^{-8}$ \\
\hline 1504 & 1703 & his $-16^{+}$ & 540 & $7 \times 10^{-6}$ & $1 \times 10^{-8}$ \\
\hline 1504 & 1703 & $\operatorname{trp}-49^{+}$ & 1040 & $4 \times 10^{-6}$ & $<10^{-8}$ \\
\hline
\end{tabular}

Table 4. Cotransduction of auxotrophic markers in R. leguminosarum

\begin{tabular}{|c|c|c|c|}
\hline Selected allele & $\begin{array}{l}\text { Coinherited } \\
\text { marker }\end{array}$ & $\begin{array}{c}\text { Percentage } \\
\text { coinheritance by } \\
\text { transduction }\end{array}$ & $\begin{array}{c}\text { Percentage } \\
\text { coinheritance by } \\
\text { conjugation* }\end{array}$ \\
\hline $\operatorname{trp}-14^{+}$ & ade-72 & 2 & \\
\hline ade $-72^{+}$ & trp-14 & 0.5 & 70 \\
\hline $\operatorname{trp}-14^{+}$ & ade-91 & 1 & \\
\hline ade-71+ & $r i b-2$ & 18 & 86 \\
\hline met $-12^{+}$ & ura- 14 & 5 & 82 \\
\hline ura- $14^{+}$ & met -12 & 10 & 82 \\
\hline
\end{tabular}

Table 5. Transduction of $R$ plasmids in $R$. leguminosarum

\begin{tabular}{|c|c|c|c|c|c|c|c|c|}
\hline $\begin{array}{l}\text { Donor } \\
\text { strain }\end{array}$ & $\begin{array}{l}\text { Recipient } \\
\text { strain }\end{array}$ & R plasmid & $\begin{array}{l}\text { Selected } \\
\text { resistance }\end{array}$ & $\begin{array}{l}\text { Unselected } \\
\text { resistance }\end{array}$ & $\begin{array}{l}\text { Trans- } \\
\text { ducing } \\
\text { phage }\end{array}$ & $\begin{array}{c}\text { No. of } \\
\text { colonies } \\
\text { with } \\
\text { selected } \\
\text { phenotype }\end{array}$ & $\begin{array}{c}\text { No. of } \\
\text { colonies } \\
\text { tested for } \\
\text { non-selected } \\
\text { markers and } \\
\text { conjugative } \\
\text { ability* }\end{array}$ & $\begin{array}{l}\text { Trans- } \\
\text { duction } \\
\text { frequency }\end{array}$ \\
\hline 1683 & 1057 & R68.45 & $\begin{array}{l}\text { Tc } \\
\text { Tc }\end{array}$ & $\begin{array}{l}\mathrm{Km} \mathrm{Ap} \\
\mathrm{Km} \mathrm{Ap}\end{array}$ & $\begin{array}{l}\text { RL38 } \\
\text { RL39 }\end{array}$ & $\begin{array}{l}40 \\
39\end{array}$ & $\begin{array}{l}31 \\
33\end{array}$ & $\begin{array}{l}1 \times 10^{-7} \\
1 \times 10^{-7}\end{array}$ \\
\hline 2202 & 1057 & pPH1JI & $\begin{array}{l}\mathrm{Ge} \\
\mathrm{Ge}\end{array}$ & $\begin{array}{l}\text { Sp } \\
\text { Sp }\end{array}$ & $\begin{array}{l}\text { RL38 } \\
\text { RL39 }\end{array}$ & $\begin{array}{l}47 \\
65\end{array}$ & $\begin{array}{l}15 \\
30\end{array}$ & $\begin{array}{l}2 \times 10^{-7} \\
2 \times 10^{-7}\end{array}$ \\
\hline
\end{tabular}

* These transductants were crossed with $E$. coli strain 402 and then tested for all drug resistance markers. In all cases tested the transduced plasmids remained conjugative and retained all the drug resistance markers of the parent.

\section{Interspecific transduction}

Phage RL38 formed plaques on $R$. trifolii strain 6621 and high phage titres could be prepared on this strain and its derivatives. The efficiency of plating of the phage was different on $R$. leguminosarum and $R$. trifolii though this difference did not seem to be due to normal restriction. Phage grown on derivatives of $R$. leguminosarum strain 300 plaqued with a tenfold higher efficiency on this strain than on $R$. trifolii strain 6621 , but phage grown on derivatives of 6621 also had an increased efficiency of plating (five- to tenfold) on strain 300 compared with 6621 .

Table 6 shows the transductions that were attempted between $R$. leguminosarum strains, between $R$. trifolii strains and between the two species. Strains carrying Tn5-induced auxo- 
Table 6. Transduction of transposon-induced auxotrophy in R. leguminosarum and $R$. trifolii using phage RL38

\begin{tabular}{|c|c|c|c|c|c|}
\hline Donor strain & Recipient strain & $\begin{array}{l}\text { Selected } \\
\text { allele }\end{array}$ & $\begin{array}{l}\text { Coinherited } \\
\text { marker }\end{array}$ & $\begin{array}{l}\text { Transduction } \\
\text { frequency }\end{array}$ & $\begin{array}{l}\text { No. of } \\
\text { colonies } \\
\text { tested } †\end{array}$ \\
\hline minosarum 1057 & R. trifolii $\mathrm{T} 72$ & $l i v-9+$ & $k_{a n}^{+}$ & $4 \times 10^{-6}$ & 224 \\
\hline minosarum 1057 & R. trifolii $\mathrm{T} 153$ & $\operatorname{trp}-59^{+}$ & $\mathrm{kan}^{+}$ & $4 \times 10^{-6}$ & 266 \\
\hline lii 6710 & R. leguminosarum T94 & ade-91+ & - & $<10^{-8}$ & - \\
\hline lii 6710 & R. trifolii $\mathrm{T} 72$ & liv-9+ & $k_{a n}^{+}$ & $3 \times 10^{-6}$ & 180 \\
\hline lii 6710 & R. trifolii T153 & $\operatorname{trp}-59+$ & $\mathrm{kan}^{+}$ & $7 \times 10^{-6}$ & 82 \\
\hline minosarum $\mathrm{T} 94$ & R. trifolii 6710 & *kan & ade-91 & $8 \times 10^{-6}$ & 532 \\
\hline lii T72 & R. leguminosarum 1057 & *kan & - & $<10^{-8}$ & - \\
\hline lii T72 & R. trifolii 6710 & *kan & liv-9 & $5 \times 10^{-6}$ & 425 \\
\hline lii T153 & R. leguminosarum 1057 & *kan & - & $<10^{-8}$ & - \\
\hline lii $\mathrm{T} 153$ & R. trifolii 6710 & *kan & $\operatorname{trp}-59$ & $3 \times 10^{-6}$ & 390 \\
\hline minosarum 1057 & R. leguminosarum T94 & ade-91+ & $\mathrm{kan}^{+}$ & $2 \times 10^{-5}$ & 100 \\
\hline minosarum T94 & R. leguminosarum 1057 & *kan & ade-91 & $1 \times 10^{-5}$ & 100 \\
\hline
\end{tabular}

*kan, Selection for kanamycin resistance carried on Tn5.

$\dagger$ In all cases, transductants selected for one marker showed coinheritance of the unselected marker.

trophic markers (Beringer et al., 1978b) were used in these transductions since they had two cotransducible markers - auxotrophy and kanamycin resistance. Transduction occurred at high frequency between $R$. leguminosarum strains and also at fairly high frequency between $R$. trifolii strains. Markers could be transduced from $R$. leguminosarum to $R$. trifolii but no transduction was detected in the reverse direction (frequency less than $10^{-8}$ ).

\section{DISCUSSION}

RL38 and RL39 are the first phages reported to be capable of mediating generalized transduction in $R$. leguminosarum. Other transduction systems in Rhizobium species have utilized temperate phages, whereas RL38 and RL39 are almost certainly virulent. The use of such phages in transduction has been reported previously. In all cases, reduction in the killing potential of the phages was required, either by u.v. pretreatment (Ely \& Johnson, 1977) or by the use of suppressible phage mutants (Drexler, 1970; Yasbin \& Young, 1974) or temperature-sensitive mutations (Campos et al., 1978). U.v. treatment of virulent phages increases the frequency of transduction because it reduces the number of plaque-forming particles and hence the killing potential of the phage lysates (Ely \& Johnson, 1977).

U.v. treatment has previously been shown to increase the transducing frequency of several temperate phages, notably P22 (Garen \& Zinder, 1955), $\lambda$ (Arber, 1958) and P1 (Luria et al., 1960). Benzinger \& Hartman (1962) found that, in P22, this increase appeared to be due to increased recombination, resulting in a higher ratio of complete to abortive transductants. The decrease in transduction frequency caused by excess u.v. irradiation of the lysates may be due to inactivation of the bacterial DNA carried in the transducing phage particles, and/or to destruction of phage functions necessary for adsorption and injection of DNA into the bacterial cell.

Transduction by RL38 and RL39 is generalized since markers from all around the chromosome were transduced. The only detectable difference between the two phages was in their transducing frequency. Their plaque morphology was the same and their cotransduction frequencies of linked markers were very similar; this may indicate a similarity in size.

The use of transduction by RL38 and RL39 to show complete coinheritance of Tn5induced auxotrophy with kanamycin resistance, as well as a complete correlation of loss of kanamycin resistance with transduction of the Tn5-induced auxotrophy to prototrophy, has already been reported for R. leguminosarum (Beringer et al., 1978b). This paper shows 
the same result for $R$. trifolii and demonstrates that transduction can occur from $R$. leguminosarum to $R$. trifolii although not, apparently, in the reverse direction.

Phage RL38 had a higher plaquing efficiency on $R$. leguminosarum than on $R$. trifolii regardless of which species was its previous host. It may be that adsorption to $R$. trifolii is slower so that fewer phage particles form plaques. The observation that transduction can occur from $R$. leguminosarum to $R$. trifolii but not from $R$. trifolii to $R$. leguminosarum cannot be explained by poor adsorption since phages grown on $R$. trifolii had a higher efficiency of plating on $R$. leguminosarum. A general system of restriction is also an unlikely explanation because DNA can be transferred from $R$. trifolii to $R$. leguminosarum by conjugation and stable recombinants are formed at similar frequencies to those obtained in crosses between strains of $R$. leguminosarum (Johnston \& Beringer, 1977). Since transduction occurs in one direction, recombination difficulties due to lack of homology in the short section of DNA are unlikely to be the explanation.

The system of generalized transduction for $R$ : leguminosarum and $R$. trifolii reported here will be useful for high-resolution mapping in these strains. The availability of interspecific transduction may allow fine structure mapping of host range genes.

I would like to thank Drs J. E. Beringer and A. W. B. Johnston for help and advice and Dr N. Brewin and Professor D. A. Hopwood for critical reading of the manuscript. I gratefully acknowledge a postgraduate studentship from the Agricultural Research Council.

\section{REFERENCES}

Adams, M. H. (1959). Bacteriophages. New York: Interscience.

ARBER, W. (1958). Transduction des caractères gal par le bactériophage lambda. Archives des sciences, Geneva 11, 259-338.

Benzinger, R. \& Hartman, P. E. (1962). Effects of ultraviolet light on transducing phage P22. Virology 18, 614-626.

BERINGER, J. E. (1974). R factor transfer in Rhizobium leguminosarum. Journal of General Microbiology 84, 188-198.

Beringer, J. E. \& Hopwood, D. A. (1976). Chromosomal recombination and mapping in Rhizobium leguminosarum. Nature, London 264, 291-293.

Beringer, J. E., HogGan, S. A. \& Johnston, A. W. B. (1978a). Linkage mapping in Rhizobium leguminosarum by means of $\mathrm{R}$ plasmid-mediated recombination. Journal of General Microbiology 104, 201-207.

Beringer, J. E., Beynon, J. L., Buchanan-WollaSTON, A. V. \& Johnston, A. W. B. (1978b). Transfer of the drug resistance transposon Tn5 to Rhizobium. Nature, London 276, 633-634.

Buchanan-Wollaston, V. (1977). John Innes Institute Annual Report, 68.

Campos, J. M., Geisselsoder, J. \& Zusman, D. R. (1978). Isolation of bacteriophage $\mathrm{Mx} 4$, a generalised transducing phage for Myxococcus xanthus. Journal of Molecular Biology 119, 167-178.

DREXLER, H. (1970). Transduction by bacteriophage T1. Proceedings of the National Academy of Sciences of the United States of America 66, 1083-1088.

Ely, B. \& JoHnson, R. C. (1977). Generalised transduction in Caulobacter crescentus. Genetics 87, 391-399.

Garen, A. \& Zinder, N. D. (1955). Radiological evidence for partial genetic homology between bacteriophage and host bacteria. Virology 1, 347376.

HaAs, D. \& Holloway, B. W. (1976). R factor variants with enhanced sex factor activity in Pseudomonas aeruginosa. Molecular and General Genetics 144, 234-251.

Hirsch, P. R. (1978). Studies of plasmids in Rhizobium leguminosarum. Ph.D. thesis, University of East Anglia.

Jacob, A. E., Cresswell, J. M. \& Hedges, R. W. (1977). Molecular characterisation of the $\mathbf{P}$ group plasmid R68 and variants with enhanced chromosome mobilising ability. FEMS Microbiology Letters 1, 71-74.

Johnston, A. W. B. \& Beringer, J. E. (1975). Identification of Rhizobium strains in pea root nodules using genetic markers. Journal of General Microbiology 87, 343-350.

Johnston, A. W. B. \& Beringer, J. E. (1977). Chromosomal recombination between Rhizobium species. Nature, London 267, 611-613.

Johnston, A. W. B., Setchell, S. M. \& Beringer, J. E. (1978a). Interspecific crosses between Rhizobium leguminosarum and $R$. meliloti: formation of haploid recombinants and of R-primes. Journal of General Microbiology 104, 209-218.

Johnston, A. W. B., Beynon, J. L., BuchananWollaston, A. V., Setchell, S. M., Hirsch, P. R. \& Beringer, J. E. $(1978 b)$. High frequency transfer of nodulating ability between strains and species of Rhizobium. Nature, London 276, 634636.

Kondorosi, A., Kiss, G. B., Forrai, T., Vincze, E. \& Banfalvi, Z. (1977). Circular linkage map of the Rhizobium meliloti chromosome. Nature, London 268, 525-527. 
KowALSKI, M. (1967). Transduction in Rhizobium meliloti. Acta microbiologica polonica 16, 7-12.

KowALSKI, M. (1970). Transducing phages of Rhizobium meliloti. Acta microbiologica polonica, ser. A. 2, 109-113.

Kowalski, M. (1974). In Symbiotic Nitrogen Fixation in Plants, pp. 63-67. Edited by P.S. Nutman. Cambridge: Cambridge University Press.

Luria, S. E., Adams, J. N. \& Ting, R. C. (1960). Transduction of lactose-utilising ability among strains of Escherichia coli and Shigella dysenteriae and the properties of the transducing particles. Virology 12, 348-390.

Meade, H. M. \& Signer, E. R. (1977). Genetic mapping of Rhizobium meliloti. Proceedings of the National Academy of Sciences of the United States of America 74, 2076-2078.

SvÁB, Z., Kondorosi, A. \& Orosz, L. (1978). Specialized transduction of a cysteine marker by Rhizobium meliloti phage 16-3. Journal of General Microbiology 106, 321-327.

VINCENT, J. M. (1970). A Manual for the Practical Study of the Root-nodule Bacteria, International Biological Programme Handbook No. 15. Oxford and Edinburgh: Blackwell Scientific Publications. YASBIN, R. E. \& Young, F. E. (1974). Transduction in Bacillus subtilis by bacteriophage SPP1. Journal of Virology 14, 1343-1348. 